\title{
Enamel matrix proteins associated with GTR and bioactive glass in the treatment of class III furcation in dogs
}

\section{Proteína da matriz do esmalte associada a R.T.G. e vidro bioativo no tratamento de furca grau III em cães}

\author{
José Marcos Alves Fernandes* \\ Rodrigo Otávio Citó César Rego* \\ Luis Carlos Spolidorio** \\ Rosemary Adriana Chiérici Marcantonio*** \\ Elcio Marcantonio Júnior*** \\ Joni Augusto Cirelli***
}

\begin{abstract}
This study investigated, both histologically and histometrically, the efficacy of enamel matrix derived proteins (EMD) associated with bioactive glass (BG) and an absorbable membrane in the treatment of class III furcation defects in mongrel dogs. After surgical defect creation and chronification, the lesions were randomly divided into three groups according to the treatment employed: Test Group 1 - EMD + BG + membrane, Test Group 2 $\mathrm{EMD}+$ membrane and Control Group - BG + membrane. After a 90-day healing period, the dogs were sacrificed. The descriptive analysis and the histometric data showed similar results for the experimental groups in all studied parameters (MANOVA, $\mathrm{p}>0.05$ ). The association of Emdogain ${ }^{\circledR}$ with bioglass and GTR, or with GTR only, showed similar results when compared with the ones obtained with bioglass associated with membrane in the treatment of class III furcation defects in dogs. The three modalities of treatment showed partial filling of the furcations, with bone and cementum regeneration limited to the apical portion of the defects.

DESCRIPTORS: Periodontal treatment; Dental enamel proteins; Bioactive glass; Guided tissue regeneration.

RESUMO: Este estudo investigou, histológica e histometricamente, a eficácia da proteína derivada da matriz de esmalte (EMD) associada com vidro bioativo (BG) e membrana absorvivel, no tratamento de defeitos de furcas classe III em cães. Após criação cirúrgica e cronificação dos defeitos, as lesões foram divididas aleatoriamente em três grupos de acordo com o tratamento proposto: Grupo Teste $1-$ EMD + BG + membrana, Grupo Teste 2 - EMD + membrana e Grupo Controle - BG + membrana. Após 90 dias do período de cicatrização, os cães foram sacrificados. A análise descritiva e os dados histométricos mostraram resultados similares para os grupos experimentais em todos os parâmetros estudados (MANOVA, p > 0,05). As associações de Emdogain com vidro bioativo e RTG, ou somente com RTG, mostraram resultados similares quando comparadas ao vidro bioativo associado à membrana no tratamento de defeito de furca classe III, em cães. As três modalidades de tratamento mostraram preenchimento parcial das furcas com regeneração óssea e cementária limitada à porção apical das mesmas.
\end{abstract}

DESCRITORES: Tratamento periodontal; Proteínas do esmalte dentário; Vidro bioativo; Regeneração tecidual guiada.

\section{INTRODUCTION}

Periodontal regeneration with complete resolution of bone defects still remains a challenge in periodontics, mainly when large defects such as class III furcation are concerned ${ }^{13,15}$.

Guided Tissue Regeneration (GTR) has been the most widely studied technique for the treatment of furcation and intraosseous defects, solely ${ }^{2,13,15}$ or in association with other biomaterials ${ }^{3,14,16}$. Among these, bioactive glass is an alloplastic material that has shown favorable results regarding the reduc- tion of probing depth, clinical attachment gain and filling of bone defects ${ }^{1,18,22}$. However, there is still low success predictability in the treatment of class III furcation defects ${ }^{6}$.

Recently, proteins derived from porcine fetal enamel matrix have been investigated as an alternative for periodontal regeneration. Their use is based upon their ability to form acellular cementum, which is important for the formation of new bone tissue and periodontal ligament ${ }^{9,10}$.

\footnotetext{
*MS Graduate Students, Department of Diagnosis and Surgery; **PhD, Assistant Professor, Department of Pathology; ***PhD, Assistant Professors, Department of Diagnosis and Surgery - School of Dentistry of Araraquara, São Paulo State University.
} 
Fernandes JMA, Rego ROCC, Spolidorio LC, Marcantonio RAC, Marcantonio Júnior E, Cirelli JA. Enamel matrix proteins associated with GTR and bioactive glass in the treatment of class III furcation in dogs. Braz Oral Res 2005;19(3):169-75.

This protein complex, in vitro, increases the migration and proliferation of cells from the periodontal ligament ${ }^{7}$, and the formation of acellular cementum, periodontal ligament and alveolar bone ${ }^{3,9,10,21}$. Clinically, in intraosseous defects, it leads to expressive reduction in probing depth and gain in attachment level ${ }^{12,20}$. The use of enamel matrix derived proteins (EMD) for the treatment of class III furcation defects was assessed by Araújo, Lindhe $^{3}$ (1998). Favorable results were observed regarding periodontal regeneration; however, they were similar to the ones obtained solely with GTR. New studies to assess this form of treatment, including the association of EMD with other biomaterials, are necessary.

The aim of the present study is to histologically assess, in dogs, the efficacy of enamel matrix derived protein associated to GTR and bioactive glass in the treatment of class III furcation defects.

\section{MATERIALS AND METHODS}

A total of 20 teeth, lower $2^{\text {nd }}$ and $4^{\text {th }}$ premolars of five mongrel dogs, were used. For clinical interventions, the animals were sedated using dihydrotiazine IM $\left(4 \mathrm{mg} / \mathrm{kg}\right.$ ) (Rompum ${ }^{\circledR}$ - Bayer do Brasil S/A, São Paulo, SP, Brazil) and anesthetized with sodium thiopental IV $(12 \mathrm{mg} / \mathrm{kg}$ ) (ABBOTT Laboratórios do Brasil Ltda., São Paulo, SP, Brazil). Four and $5 \mathrm{~mm}$ high class III furcation defects were created, respectively, on the $2^{\text {nd }}$ and $4^{\text {th }}$ premolars. After the reflection of a mucoperiosteal flap, osteotomy followed by vigorous scaling of the root surface was performed. Bone cavities were filled with gutta percha (Odahcam, Herpe Produtos Dentários Ltda., Rio de Janeiro, RJ, Brazil) to avoid spontaneous regeneration of the defects ${ }^{5}$. Extraction of the lower $1^{\text {st }}$ and $3^{\text {rd }}$ premolars was performed to facilitate the repositioning of the flaps, which were coronally sutured (Ethicon 4.0, Johnson \& Johnson, São Paulo, SP, Brazil).

After a week, sutures were removed. The animals were kept with no oral hygiene control and a soft diet for eight weeks to favor plaque accumulation. Afterwards, the gutta percha was removed and the animals received supragingival scaling and dental prophylaxis. A week later, mucoperiosteal flap was raised in the region and displaced in such a way to expose the furcation defects (Figure 1). The defects were submitted to curettage (Neumar, São Paulo, SP, Brazil) and the root surfaces were scaled and planned. Then, a reference notch was done using a \# 1/ 2 carbide bur (KG Sorensen, São Paulo, SP, Brazil) on the root surface of the defect, on the alveolar bone crest level, to help the delimitation of the defect during histological analysis. Teeth were randomly divided into three groups according to the treatment form, providing that each dog had, at least, one tooth in each group:

Test Group 1 (G1) - root surfaces were conditioned with 24\% EDTA (Farmácia Santa Paula, Araraquara, SP, Brazil) for two minutes with cotton pellets rubbed on the surface and changed each 30 seconds. The root surface was rinsed with saline and Emdogain ${ }^{\circledR}$ (Biora Inc., Chicago, IL, USA) was applied according to the manufacturer's instructions. The defects were filled with bioactive glass (PerioGlass $^{\circledR}$, US Biomaterial Corporation, Florida, USA) and protected with absorbable membranes (Resolut XT, W.L.Gore \& Associates Inc., Arizona, USA) on the vestibular and lingual surfaces. The membranes were fixed with suspended resorbable sutures (WL Gore \& Associates Inc., Flagstaff, AZ, USA) around the cervical region of the tooth, covering the entire defect and 2 to $3 \mathrm{~mm}$ of the surrounding bone tissue. Flaps were coronally repositioned with interrupted and suspended silk sutures (Ethicon 4.0, Johnson \& Johnson, São Paulo, SP, Brazil) (Figures 2 and 3).

Test Group 2 (G2) - the defects received the same treatment described in Test Group 1, except for the placement of the bioactive glass.

Control Group (G3) - the defects received the same treatment described in Test Group 1, except for the placement of Emdogain ${ }^{\circledR}$ and root conditioning with 24\% EDTA.

At the end of surgery, the dogs received IM injections of antibiotics (penicillin $\mathrm{G}$ benzathine, 40.000 UI/kg - Fort Dodge Saúde Animal Ltda., Campinas, SP, Brazil) and analgesics (dipyrone Magnopyrol ${ }^{\circledR}$, ABBOTT Laboratórios do Brasil Ltda., São Paulo, SP, Brazil, $2 \mathrm{ml} / 10 \mathrm{~kg}$ ) as postoperative

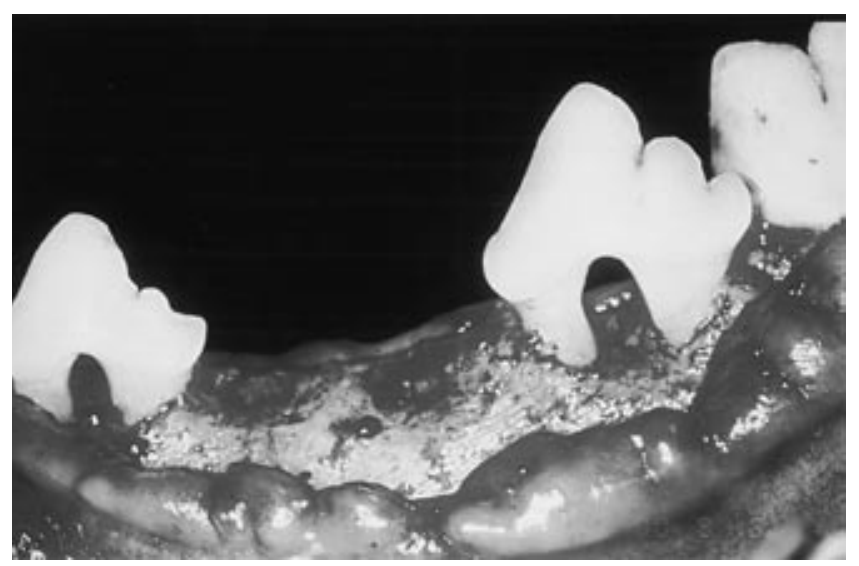

FIGURE 1 - Class III furcation defects after the chronification period. 
Fernandes JMA, Rego ROCC, Spolidorio LC, Marcantonio RAC, Marcantonio Júnior E, Cirelli JA. Enamel matrix proteins associated with GTR and bioactive glass in the treatment of class III furcation in dogs. Braz Oral Res 2005;19(3):169-75.

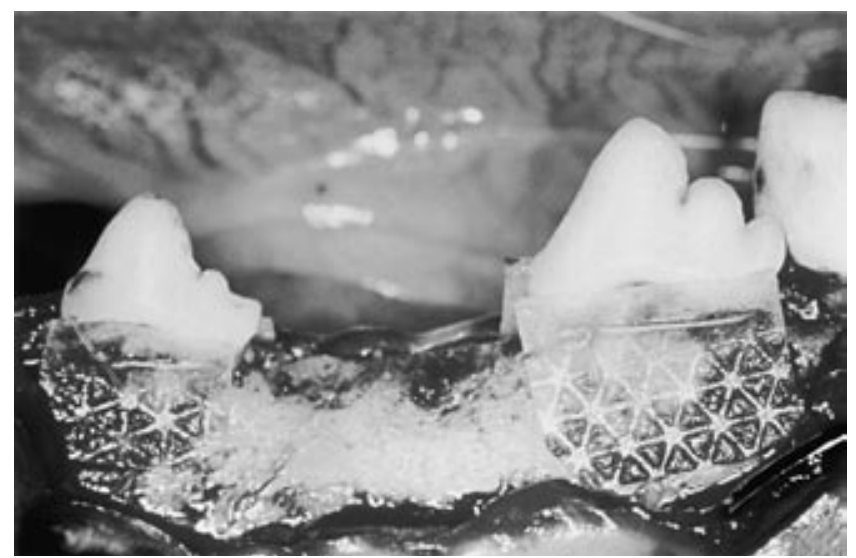

FIGURE 2 - Absorbable membrane fixed with suspended sutures in the vestibular and lingual aspects of the defect.

medications. The animals were kept for 90 days with soft feeding to avoid suture rupture or displacement of the graft material. Over this period, plaque control by application of $2 \%$ chlorhexidine gel (Farmácia Santa Paula, Araraquara, SP, Brazil) was performed, five days per week. Sutures were removed 10 days after the surgery.

After the 90-day period, the animals were sacrificed by means of an overdose of sodium thiopental. Teeth were removed in blocks, fixed in formalin and decalcified in Morse solution. Routine histologic processing and paraffin embedding were carried out, and $5 \mu \mathrm{m}$ thick tissue slices were obtained from the tissue blocks longitudinally, in a mesiodistal direction, in a way to obtain a panoramic view of the furcation area.

For histometric and descriptive histological analyses, five cuts were selected, including the first and the last ones, which evidenced the reference notches in both roots. These two cuts served as reference for the selection of the other three that were selected in a way to show a constant distance among them. The cuts represented the vestibular, lingual and median portions of the furcation in a buccolingual direction. These selected sections were stained with hematoxylin and eosin $(\mathrm{H} / \mathrm{E})$ and Masson's Trichrome.

For the performance of a blind descriptive histological analysis, the slices were codified according to the animal and the group, in such a way that the observer was blinded. Software for digital image analysis (Jandel Sigma Scan Pro, Jandel Corporation, San Rafael, CA, USA) was used for the measurements (schematically represented in Figure 4).

The following linear and area measurements were obtained during the histometric analysis:



FIGURE 3 - Flap repositioned and sutured.

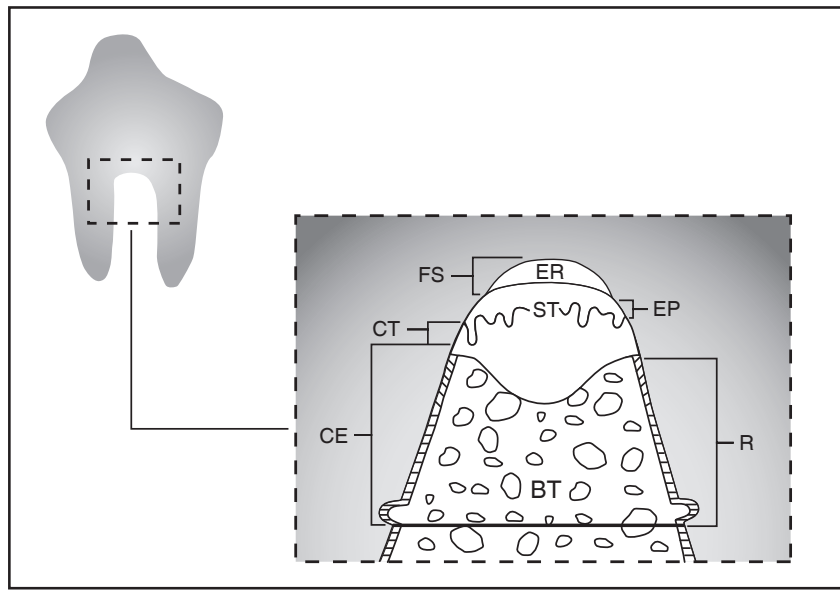

FIGURE 4 - Linear and area variables evaluated in the histometric analysis. $\mathrm{ER}=$ empty region area, $\mathrm{ST}=$ soft tissue area, $\mathrm{BT}=$ bone tissue area, FS = free surface, EP = epithelial migration, $\mathrm{CT}=$ connective tissue, $\mathrm{CE}=$ cementum formation, $\mathrm{R}$ = periodontal regeneration.

1. total root extension of the defect - linear root surface of the defect between the notches on the mesial and distal roots;

2. cementum formation $(\mathrm{CE})$ - sum of the linear extensions of the root surface of the defect covered by new cementum;

3. epithelial migration (EP) - linear extension of the root surface of the defect covered by epithelial tissue;

4. connective tissue (CT) - linear extension of the root surface of the defect with connective tissue in direct contact with it;

5. periodontal regeneration $(\mathrm{R})$ - sum of the linear extensions of the root surface of the defect covered by new cementum adjacent to new bone tissue; 
Fernandes JMA, Rego ROCC, Spolidorio LC, Marcantonio RAC, Marcantonio Júnior E, Cirelli JA. Enamel matrix proteins associated with GTR and bioactive glass in the treatment of class III furcation in dogs. Braz Oral Res 2005;19(3):169-75.

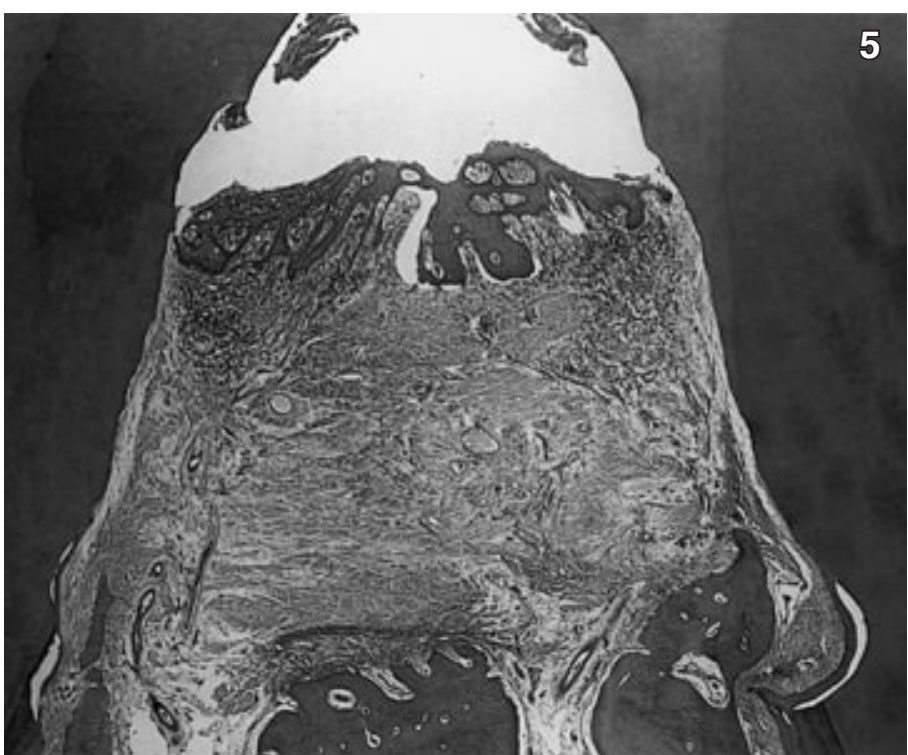

FIGURE 5 - Test Group 1 - panoramic view of the defect showing an empty space on the coronal region and new bone and cementum limited to the notch area (hematoxylin and eosin, original magnification $25 \mathrm{X}$ ).

FIGURE 6 - Test Group 2 - panoramic view of the lesion demonstrating considerable extension of new cementum. New bone was limited to the apical portion of the furcation defect (hematoxylin and eosin, original magnification $25 \mathrm{X})$.

6. free surface (FS) - linear extension of the root surface of the defect not filled with any kind of tissue and in contact with plaque;

7. total area of the defect - furcation area apically limited by a line joining both notches;

8. bone tissue area (BT) - portion of the total area of the defect filled with new bone;

9. soft tissue area (ST) - portion of the total area of the defect filled with connective and epithelial tissue;

10. empty region area (ER) - portion of the total area of the defect without the presence of any type of tissue, partially filled with plaque deposited on the root surface.

Multivariate analysis of variance at a 5\% level of significance was used to determine whether linear and area variables were influenced by different modalities of treatment.

\section{RESULTS}

For the descriptive histological and histometric analysis, seven teeth from group G1, six from G2 and four from group G3 were used, composing

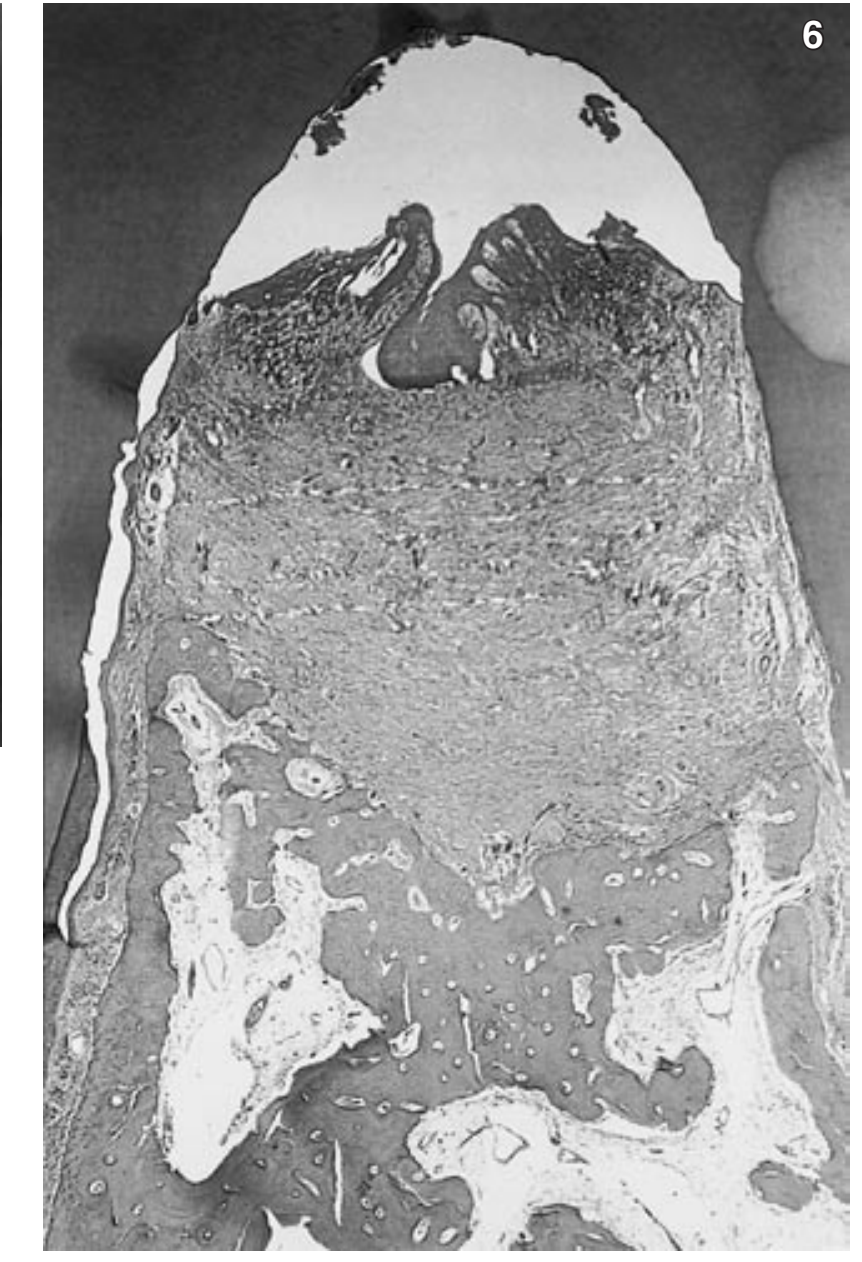

a total of 17 teeth (three teeth were lost during histological processing).

\section{Descriptive histological analysis}

Test Groups 1 and 2 - (Figures 5 and 6) The notches produced on the root surface were partially or totally covered by new cellular cementum that extended in a coronal direction and varied in thickness and height. In contiguity, there were collagen fibers bundles of variable thickness inserted into the new cementum. In some teeth, formation of new bone was observed, limited to the region of the notches neighboring the collagen bundles.

On the coronal region of the lesion, the collagen fiber bundles were interposed by leukocyte infiltration subjacent to a stratified epithelium. In proximity or in contact with the furcation roof, variable quantity of amorphous material was observed, which indicates bacterial plaque.

Control Group - (Figures 7 and 8) In this group, on the coronary portion of the defect, the 
Fernandes JMA, Rego ROCC, Spolidorio LC, Marcantonio RAC, Marcantonio Júnior E, Cirelli JA. Enamel matrix proteins associated with GTR and bioactive glass in the treatment of class III furcation in dogs. Braz Oral Res 2005;19(3):169-75.
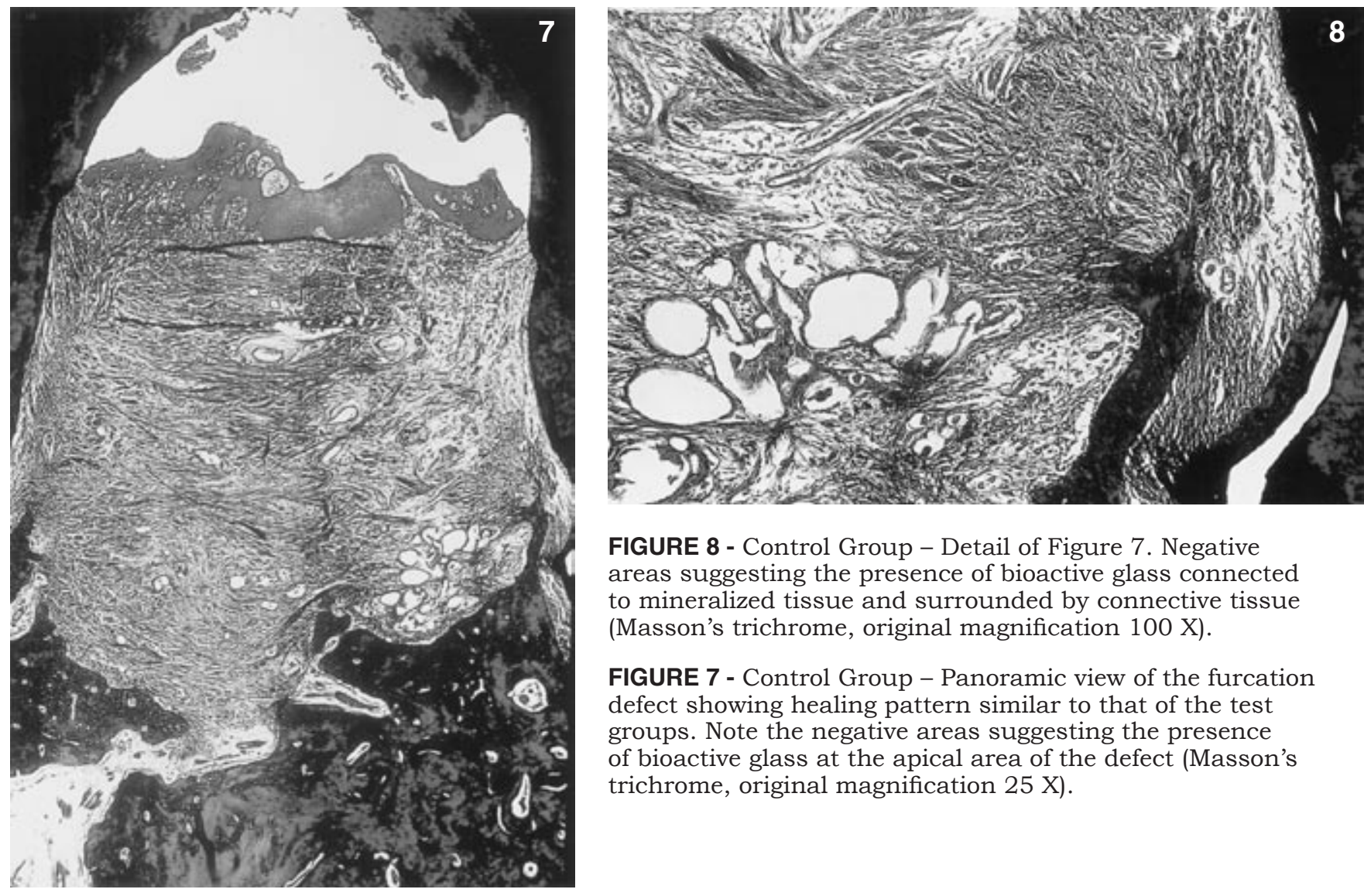

FIGURE 8 - Control Group - Detail of Figure 7. Negative areas suggesting the presence of bioactive glass connected to mineralized tissue and surrounded by connective tissue (Masson's trichrome, original magnification $100 \mathrm{X}$ ).

FIGURE 7 - Control Group - Panoramic view of the furcation defect showing healing pattern similar to that of the test groups. Note the negative areas suggesting the presence of bioactive glass at the apical area of the defect (Masson's trichrome, original magnification $25 \mathrm{X}$ ).

epithelial tissue was present with variable thickness. A subjacent inflammatory reaction mainly composed of mononuclear cells was present, probably due to the presence of bacterial plaque on the roof of the furcation. The new cementum and new bone formation was similar to that in test groups. In the notch level, negative areas suggested the presence of bioactive glass.

\section{Histometric analysis}

Data obtained in millimeter by histometric analysis were converted into a percentage relative to the total area or linear extension of each defect to minimize the interference of the size of teeth in the results of the analyses.

Tables 1 and 2 show the results for descriptive statistics, and statistical analysis of linear and area measures. The multivariate analysis of variance did not show significant difference among the means of the groups for linear $(p=0.6822)$ and area measurements $(\mathrm{p}=0.2297)$, in such a way that there is no statistical evidence that one treatment is different from the other.

\section{DISCUSSION}

The employment of regenerative techniques in the treatment of class III furcation defects has shown few favorable results for periodontal regeneration ${ }^{6,13,15}$.

Recently, enamel matrix-derived proteins (EMD) have been used alone or associated with biomaterials and regenerative techniques in order to increase the amount of tissue regeneration. Although favorable results have been observed after the association with bone grafts ${ }^{4,11,12}$, studies that demonstrate the increment obtained by these techniques when EMD is added are still lacking.

In this study, EMD was associated with GTR and to bioactive glass or to GTR only, for the treatment of class III furcation defects. Among the materials that have been used for filling bone defects, bioactive glass represents a new class of synthetic materials. This material prevents differentiation of precursor cells into osteoclasts and has optimal capacity to promote osteoconduction as well as to induce differentiation of osteoprogenitor cells into osteoblasts $^{17}$. 
Fernandes JMA, Rego ROCC, Spolidorio LC, Marcantonio RAC, Marcantonio Júnior E, Cirelli JA. Enamel matrix proteins associated with GTR and bioactive glass in the treatment of class III furcation in dogs. Braz Oral Res 2005;19(3):169-75.

TABLE 1 - Descriptive Statistics for Linear and Area Variables according to treatment groups.

\begin{tabular}{|c|c|c|c|c|}
\hline Variable & Group & $\mathrm{N}$ (teeth) & Mean (\%) & $\mathrm{SD}$ \\
\hline \multirow{3}{*}{$\begin{array}{l}\text { Cementum } \\
\text { Formation }\end{array}$} & 1 & 7 & 24.2 & 9.2 \\
\hline & 2 & 6 & 17.2 & 9.5 \\
\hline & 3 & 4 & 14.2 & 9.0 \\
\hline \multirow{3}{*}{$\begin{array}{l}\text { Connective } \\
\text { Tissue }\end{array}$} & 1 & 7 & 10.0 & 4.9 \\
\hline & 2 & 6 & 7.7 & 5.0 \\
\hline & 3 & 4 & 6.6 & 6.5 \\
\hline \multirow{3}{*}{$\begin{array}{l}\text { Epithelium } \\
\text { Migration }\end{array}$} & 1 & 7 & 23.2 & 8.5 \\
\hline & 2 & 6 & 24.8 & 13.7 \\
\hline & 3 & 4 & 22.1 & 8.5 \\
\hline \multirow{3}{*}{$\begin{array}{l}\text { Free } \\
\text { Surface }\end{array}$} & 1 & 7 & 42.7 & 13.7 \\
\hline & 2 & 6 & 50.3 & 9.4 \\
\hline & 3 & 4 & 57.1 & 16.8 \\
\hline \multirow{3}{*}{$\begin{array}{l}\text { Periodontal } \\
\text { Regeneration }\end{array}$} & 1 & 7 & 6.3 & 6.4 \\
\hline & 2 & 6 & 1.0 & 2.5 \\
\hline & 3 & 4 & 1.5 & 3.1 \\
\hline \multirow{3}{*}{$\begin{array}{l}\text { Bone Tissue } \\
\text { Area }\end{array}$} & 1 & 7 & 2.0 & 2.9 \\
\hline & 2 & 6 & 0.1 & 0.3 \\
\hline & 3 & 4 & 0.8 & 1.7 \\
\hline \multirow{3}{*}{$\begin{array}{l}\text { Empty } \\
\text { Region Area }\end{array}$} & 1 & 7 & 26.3 & 15.7 \\
\hline & 2 & 6 & 35.0 & 13.4 \\
\hline & 3 & 4 & 45.5 & 16.7 \\
\hline \multirow{3}{*}{$\begin{array}{l}\text { Soft Tissue } \\
\text { Area }\end{array}$} & 1 & 7 & 71.7 & 13.7 \\
\hline & 2 & 6 & 64.8 & 13.2 \\
\hline & 3 & 4 & 53.7 & 16.4 \\
\hline
\end{tabular}

The results did not show histological differences among test and control groups. The latter was treated with GTR and bioglass only. It is important to mention that the number of animals is a fragile point to be considered and a limitation to find differences among groups. Nevertheless, periodontal regeneration was limited in all teeth, regardless the type of treatment. Of the three groups, Test Group 1 showed greater cementum formation (24.2\% of the root extension of the defect), but with no statistical difference in relation to the other groups. These results do not corroborate the ones reported by Araújo, Lindhe ${ }^{3}$ (1998), who observed cementum formation in all the root extension of class III furcation defects with the use of EMD and membrane. Better results were also observed in other studies when regenerative techniques were employed for the treatment of class III furcation $\operatorname{defects}^{13,14,16}$.
TABLE 2 - Results of MANOVA for grouped Linear and Area Variables.

\begin{tabular}{l|c|l|c|c|c}
\hline \hline Variable & $\begin{array}{c}\text { Wilks' } \\
\text { Lambda }\end{array}$ & R of Rao & df 1 & df 2 & p \\
\hline Linear $^{\dagger}$ & 0.6326 & 0.7075 & 8 & 22 & $0.6822^{*}$ \\
\hline Area $^{\ddagger}$ & 0.66 & 1.51 & 4 & 26 & $0.2297^{*}$ \\
\hline \hline
\end{tabular}

*Statistically not significant. 'group formed by Linear variables except for Connective Tissue. ${ }^{\ddagger}$ Group formed by Area variables except for Bone Tissue Area. df: degrees of freedom. Rao: Rao's score test.

Several factors may influence the extension of the new cementum. The presence of remaining original cementum on the roots, the size of the defect, the level of epithelial migration, the presence of gingival recession, the occurrence of trauma in the site during the healing period and the observation time of the study are responsible for the variation of results among studies and among teeth of a particular study ${ }^{8}$.

The reason for the employment of EMD in regenerative treatment is the formation of a new layer of acelular cementum ${ }^{9,10}$. Araújo, Lindhe ${ }^{3}$ (1998) verified formation of acellular and cellular cementum in the apical and coronary portions of class III furcation defects, respectively. Yukna, Mellonig ${ }^{21}$ (2000) also observed the formation of two types of cementum in the treatment of intrabony defects in humans. However, in the present study, the neoformation of cellular cementum alone was observed, the same observed by Sculean et al. ${ }^{19}$ (1999) when treating intrabony defects. However, the advantages of acellular over cellular cementum for periodontal regeneration are not clearly defined. Araújo, Lindhe ${ }^{3}$ (1998) reported similar bone and periodontal ligament formation for control and test groups despite the fact that acellular cementum formation had been observed only in the test group.

In the assessment of bone filling in the defects, minimal bone formation was observed, limited to the basis of the defect, in the three groups studied. Similarly to the cementum formation, bone formation was also inferior when compared with the one observed in prior studies for regenerative treatment of class III furcation defects associated or not with Emdogain ${ }^{\circledR 3,16}$. Based on these results, it should be considered that the technique employed is only one of the factors that interfere with regeneration, and that other specific factors for each patient and defect are fundamental for the success of treatment. 
Fernandes JMA, Rego ROCC, Spolidorio LC, Marcantonio RAC, Marcantonio Júnior E, Cirelli JA. Enamel matrix proteins associated with GTR and bioactive glass in the treatment of class III furcation in dogs. Braz Oral Res 2005;19(3):169-75.

\section{CONCLUSIONS}

Considering the limitations of this study, it can be concluded that the association of Emdogain ${ }^{\circledR}$ with bioactive glass and GTR, or with GTR solely showed similar results when compared to the ones obtained with bioactive glass associated with membrane in the treatment of class III furcation defects in dogs. The three modalities of treatment showed partial filling of the furcations, with bone and cementum regeneration limited to the apical portion of the defects.

\section{REFERENCES}

1. Anderegg CR, Alexander DC, Freidman M. A bioactive glass particulate in the treatment of molar furcation invasions. J Periodontol 1999;70:384-7.

2. Araújo MG, Berglundh T, Lindhe J. GTR treatment of degree III defects with 2 different resorbable barriers. An experimental study in dogs. J Clin Periodontol 1998;25:253-9.

3. Araújo MG, Lindhe J. GTR treatment of degree III furcation defects following application of enamel matrix proteins. $\mathrm{J}$ Clin Periodontol 1998;25:524-30.

4. Boyan BD, Weesner TC, Lohman TC, Andreacchio D, Carnes DL, Dean DD, et al. Porcine fetal enamel matrix derivative enhances bone formation induced by demineralized freeze dried bone allograft in vivo. J Periodontol 2000;71:1278-86.

5. Cirelli JA, Marcantonio E Jr, Adriana R, Marcantonio C, Lia RC, Goissis G, Rossa C Jr. Evaluation of anionic collagen membranes in the treatment of class II furcation lesions: a histometric analysis in dogs. Biomaterials 1997;18;1227-34.

6. Garret S. Periodontal regeneration around natural teeth. Ann Periodontol 1996;1:621-66.

7. Gestrelius S, Andersson C, Lidstrom D, Hammarstrom $\mathrm{L}$, Somerman M. In vitro studies on periodontal ligament cells and enamel matrix derivative. J Clin Periodontol 1997;24:685-92.

8. Gottlow J, Nyman S, Lindhe J, Karring T, Wennstrom J. New attachment formation in the human periodontium by guided tissue regeneration. Case reports. J Clin Periodontol 1986;13:604-16.

9. Hammarström L. Enamel matrix, cementum development and regeneration. J Clin Periodontol 1997;24,658-68.

10. Heij1 L. Periodontal regeneration with enamel matrix derivative in one human experimental defect. J Clin Periodontol 1997;24:693-6.

11. Lekovic V, Camargo PM, Weinlaender M, Kenney EB, Vasilic N. Combination use of bovine porous bone mineral, enamel matrix proteins, and a bioabsorbable membrane in intrabony periodontal defects in humans. J Periodontol 2001;72:583-9.

12. Lekovic V, Camargo PM, Weinlaender M, Nedic M, Aleksic Z, Kenney EB. A comparison between enamel matrix proteins used alone or in combination with bovine porous bone mineral in the treatment of intrabony periodontal defects in humans. J Periodontol 2000;71:1110-6.

13. Lindhe $\mathrm{J}$, Pontoriero $\mathrm{R}$, Berglundh $\mathrm{T}$, Araujo $\mathrm{M}$. The effect of flap management and bioresorbable occlusive devices in GTR treatment of degree III furcation de-

\section{ACKNOWLEDGMENTS}

The authors wish to thank CAPES (Coordination for the Improvement of Higher Education Personnel) for the financial support provided. We are also grateful to Mrs. Ana Claudia G. C. Miranda, Lab Technician (Department of Diagnosis and Surgery, School of Dentistry of Araraquara, São Paulo State University) and to Mrs. Solange Aranha, for the English grammar review.

fects. An experimental study in dogs. J Clin Periodontol 1995;22:276-83.

14. Park JB, Matsuura M, Han KV, Norderyd O, Lin WL, Genco RI, et al. Periodontal regeneration in class III furcation defects of beagle dogs using guided tissue regenerative therapy with platelet-derived growth factor. J Periodontol 1995;66:462-77.

15. Pontoriero R, Lindhe J, Nyman S, Karring T, Rosenberg E, Sanavi F. Guided tissue regeneration in the treatment of furcation defects in mandibular molars. A clinical study of degree III involvements. J Clin Periodontol 1989;16:170-4.

16. Rossa Jr C, Marcantonio Jr E, Cirelli JA, Marcantonio RAC, Spolidorio LC, Fogo JC. Regeneration of class III furcation defects with basic fibroblast growth factor (b-FGF) associated with GTR. A descriptive and histometric study in dogs. J Periodontol 2000;71:775-84.

17. Schepers EJ, Ducheyne P, Barbier L, Schepers S. Bioactive glass particles of narrow size range: a new material for the repair of bone defects. Implant Dent 1993;2(3):151-6.

18. Sculean A, Barbe G, Chiantella GC, Arweiler NB, Berakdar M, Brecx M. Clinical evaluation of an enamel matrix protein derivative combined with a bioactive glass for the treatment of intrabony periodontal defects in humans. J Periodontol 2002;73:401-8.

19. Sculean A, Donos N, Blaes A, Lauermann M, Reich E, Brecx M. Comparison of enamel matrix proteins and bioabsorbable membranes in the treatment of intrabony periodontal defects. A split-mouth study. J Periodontol 1999;70:255-62.

20. Windisch P, Sculean A, Klein F, Toth V, Gera I, Reich $\mathrm{E}$, et al. Comparison of clinical, radiographic and histometric measurements following treatment with guided tissue regeneration on enamel matrix proteins in human periodontal defects. J Periodontol 2002;73:409-17.

21. Yukna RA, Mellonig JT. Histologic evaluation of periodontal healing in humans following regenerative therapy with enamel matrix derivative. A 10 -case series. J Periodontol 2000;71:752-9.

22. Zamet JS, Darbar UR, Griffiths GS, Bulman JS, Bragger $\mathrm{U}$, Burgin $\mathrm{W}$, et al. Particulate bioglass as a grafting in the treatment of periodontal intrabony defects. J Clin Periodontol 1997;24:410-8.

Received for publication on Mar 23, 2005

Sent for alterations on May 09, 2005

Accepted for publication on Jun 27, 2005 